\title{
Simulating maize phenology as a function of air temperature with a linear and a nonlinear model
}

\author{
Nereu Augusto Streck(1), Isabel Lago(1), Luana Fernandes Gabriel(1) and Flavia Kaufmann Samboranha ${ }^{(1)}$
}

(1)Universidade Federal de Santa Maria, Centro de Ciências Rurais, Departamento de Fitotecnia, CEP 97105-900 Santa Maria, RS. E-mail:nstreck2@yahoo.com.br, isalago08@yahoo.com.br, Ihuanynha@yahoo.com.br, artemis.ufsm@hotmail.com

\begin{abstract}
The objective of this study was to adapt a nonlinear model (Wang and Engel - WE) for simulating the phenology of maize (Zea mays L.), and to evaluate this model and a linear one (thermal time), in order to predict developmental stages of a field-grown maize variety. A field experiment, during 2005/2006 and 2006/2007 was conducted in Santa Maria, RS, Brazil, in two growing seasons, with seven sowing dates each. Dates of emergence, silking, and physiological maturity of the maize variety BRS Missões were recorded in six replications in each sowing date. Data collected in 2005/2006 growing season were used to estimate the coefficients of the two models, and data collected in the 2006/2007 growing season were used as independent data set for model evaluations. The nonlinear WE model accurately predicted the date of silking and physiological maturity, and had a lower root mean square error (RMSE) than the linear (thermal time) model. The overall RMSE for silking and physiological maturity was 2.7 and 4.8 days with WE model, and 5.6 and 8.3 days with thermal time model, respectively.
\end{abstract}

Index terms: Zea mays, degree days, development, modeling, thermal time.

\section{Simulação da fenologia do milho em função da temperatura do ar por um modelo linear e um não linear}

\begin{abstract}
Resumo - O objetivo deste trabalho foi adaptar um modelo não linear (Wang e Engel - WE), para simular a fenologia do milho (Zea mays L.), e avaliar esse modelo e um modelo linear (soma térmica), para estimar os estágios de desenvolvimento de uma variedade de milho cultivada em campo. Um experimento de dois anos, com sete datas anuais de semeadura cada ano, foi conduzido em Santa Maria, RS, durante os anos agrícolas 2005/2006 e 2006/2007. Foram registradas as datas de emergência, espigamento e maturação fisiológica da variedade de milho BRS Missões, em seis repetições, em cada data de semeadura. Os dados coletados no ano agrícola 2005/2006 foram usados para estimar os coeficientes dos dois modelos, e os dados coletados no ano agrícola 2006/2007 foram usados como dados independentes para avaliar os modelos. O modelo não linear (WE) estimou com precisão as datas de espigamento e maturação fisiológica e apresentou a raiz do quadrado médio do erro (RQME) menor que o modelo linear (soma térmica). A RQME geral para espigamento e maturação fisiológica foi 2,7 e 4,8 dias, com o modelo de WE, e 5,6 e 8,3 dias com o modelo da soma térmica, respectivamente.
\end{abstract}

Termos para indexação: Zea mays, graus-dia, desenvolvimento, modelagem, soma térmica.

\section{Introduction}

Growth and development are different although related processes. Plant growth refers to irreversible increase in organ or whole plant dimensions (length, area, volume, weight), and plant development refers to processes related to cell differentiation, organ initiation (morphogenesis), organ appearance, and extends to plant senescence (Streck et al., 2003). The simulation of plant development is an important tool, which may help growers to track crop development, and is part of many crop simulation models (Costa \& Barros, 2001). Photoassimilates are partitioned to different organs depending upon the developmental stage. Selection of adapted genotypes and field crop management practices - such as fertilization, pests control and irrigation scheduling - are better based on developmental stages than on calendar days (Streck et al., 2003). Accurate prediction of crop development is also very important in studies of the performance of agroecosystems under climate change scenarios (Streck \& Alberto, 2006). 
Maize (Zea mays L.) development is primarily driven by temperature (Coelho \& Dale, 1980; Warrington \& Kanemasu, 1983; Cutforth \& Shaykewich, 1990), with air temperature being assumed to drive maize development from emergence to physiological maturity (Daughtry et al., 1984; Cutforth \& Shaykewich, 1990). There are several models used to simulate maize development, which can be grouped into two categories with respect to temperature effects on development: linear models that use the well-known concept of thermal time or degree-days (Gilmore \& Rogers, 1958; Daynard, 1972; Major et al., 1983) and nonlinear models (Coelho \& Dale, 1980; Cutforth \& Shaykewich, 1990).

Linear models are attractive mainly because they are simple. In its simplest form, the thermal time is calculated by accumulating the difference between mean daily air temperature and the base temperature (Gilmore \& Rogers Júnior, 1958). A refinement of the simplest thermal time approach is to consider an upper threshold temperature, and a linear decrease in the accumulated thermal time beyond an optimum value down to zero, at the maximum temperature (Streck et al., 2006, 2007). Thermal time is often a better time descriptor than calendar days (days after planting or emergence, day of the year) (Gilmore \& Rogers Júnior, 1958; Russelle et al., 1984; McMaster \& Smika, 1988), but not always (Sentelhas \& Ungaro, 1998; Yuan \& Bland, 2005).

However, the thermal time approach is open to criticism, because of the assumption of a linear relationship between temperature and development, which is not completely realistic from a biological viewpoint. Biological processes, including plant development, respond to temperature in a nonlinear fashion, with only a small portion of the response being linear (Granier \& Tardieu, 1998; Wang \& Engel, 1998; Bonhomme, 2000). Nonlinear models have provided better predictions of development events than linear models in different crops such as wheat (Schroder \& Sondgerath, 1996), potato (Fleisher et al., 2006), muskmelon (Streck et al., 2006), eucalyptus seedlings (Martins \& Streck, 2007), and maize (Cutforth \& Shaykewich, 1990).

The Wang-Engel (WE) model (Wang \& Engel, 1998) simulates crop development considering the nonlinear effects of environmental factors (e.g. air temperature) on development with the multiplicative approach. The multiplicative approach is more biologically sound to represent the interactions between plant development and environmental factors than other approaches such as the additive or the limiting factor ones (Streck et al., 2003). However, the WE model, which was originally developed for winter wheat (Wang \& Engel, 1998), was used to simulate development in other annual crops such as potato (Streck et al., 2007), but not in maize.

The objective of this study was to adapt the WE model for simulating the phenology of maize, and to evaluate WE and thermal time models, in order to predict developmental stages of a field-grown maize variety.

\section{Materials and Methods}

In the WE model (Wang \& Engel, 1998), environmental factors are represented by response functions that range from zero to one. The temperature response function in the WE model is described by a beta function, which has three coefficients with biological meaning, i.e., minimum, optimum and maximum temperatures for development. When the temperature response function is zero, development does not take place, which occurs when temperature is below the minimum or above the maximum temperature. Development takes place at the maximum rate if the response function is one, which occurs when temperature is at optimum.

In this WE model application, the developmental cycle of maize crop was divided into two phases (Ritchie et al., 1997): vegetative phase, from emergence (EM) to silking (SI); and reproductive phase, from SI to physiological maturity (PM). The first step in the WE model is to calculate the daily rate of plant development (r). The developmental stage (DS) is calculated by accumulating the daily development rate values (i.e. at a one day time step, DS $=\Sigma \mathrm{r}$ ). DS is 0 at EM, 1 at SI, and 2 at PM (Costa \& Barros, 2001). The general form of the WE model is:

$\mathrm{r}=\mathrm{r}_{\text {max }, \mathrm{v}} \mathrm{f}(\mathrm{T})$

for the vegetative phase (EM-SI), and

$\mathrm{r}=\mathrm{r}_{\text {max }, \mathrm{r}} \mathrm{f}(\mathrm{T})$

for the reproductive phase (SI-PM), in which: $r_{\max , v}$ and $r_{\text {max }, r}$ are the maximum development rate (per day), in the vegetative and reproductive phases, respectively; and $f(T)$ is a temperature response function, which varies from 0 to 1 . The temperature response function $f(T)$ is a beta function:

$\mathrm{f}(\mathrm{T})=0, \mathrm{~T}<\mathrm{T}_{\text {min }}$

$\mathrm{f}(\mathrm{T})=\left[2\left(\mathrm{~T}-\mathrm{T}_{\mathrm{min}}\right)^{\alpha}\left(\mathrm{T}_{\mathrm{opt}}-\mathrm{T}_{\mathrm{min}}\right)^{\alpha}-\left(\mathrm{T}-\mathrm{T}_{\mathrm{min}}\right)^{2 \alpha}\right] /\left(\mathrm{T}_{\mathrm{opt}}-\right.$

$\left.\mathrm{T}_{\min }\right)^{2 \alpha}, \mathrm{T}_{\min } \leq \mathrm{T} \leq \mathrm{T}_{\max }$ 
$\mathrm{f}(\mathrm{T})=0, \mathrm{~T}>\mathrm{T}_{\max }$

$\alpha=\ln (2) / \ln \left[\left(\mathrm{T}_{\max }-\mathrm{T}_{\min }\right) /\left(\mathrm{T}_{\text {opt }}-\mathrm{T}_{\min }\right)\right]$

in which: $\mathrm{T}_{\min }, \mathrm{T}_{\mathrm{opt}}$, and $\mathrm{T}_{\max }$ are the cardinal temperatures for development (minimum, optimum, and maximum temperature, respectively); and $\mathrm{T}$ is the air temperature. It was assumed that $\mathrm{T}_{\min }=8^{\circ} \mathrm{C}$, $\mathrm{T}_{\mathrm{opt}}=28^{\circ} \mathrm{C}$, and $\mathrm{T}_{\max }=36^{\circ} \mathrm{C}$ (Cutforth \& Shaykewich, 1990), for both vegetative and reproductive phases. The shape of the curve of $f(T)$ with the cardinal temperatures for development in maize is in Figure 1. The $f(T)$ was calculated using daily minimum (TN) and daily maximum (TX) air temperature and, then, the mean of the resulting daily values of $f(T)$ were calculated, corresponding to the daily mean $f(T)$. This approach was used, because in a nonlinear function it is more appropriate to calculate the minimum and the maximum daily mean temperature first, and then to calculate the $\mathrm{f}(\mathrm{T})$.

It was also used the thermal time (TT) approach to predict maize developmental stages. Daily values of thermal time $\left({ }^{\circ} \mathrm{C}\right.$ day) were calculated as (Streck et al., 2007):

$\mathrm{TT}=0, \mathrm{~T}<\mathrm{T}_{\mathrm{b}}$

$\mathrm{TT}=\left(\mathrm{T}-\mathrm{T}_{\mathrm{b}}\right) \times 1$ day, $\mathrm{T}_{\mathrm{b}} \leq \mathrm{T} \leq \mathrm{T}_{\mathrm{opt}}$

$\mathrm{TT}=\left(\mathrm{T}_{\max }-\mathrm{T}\right)\left(\mathrm{T}_{\mathrm{opt}}-\mathrm{T}_{\mathrm{b}}\right) /\left(\mathrm{T}_{\max }-\mathrm{T}_{\mathrm{opt}}\right) \times 1$ day, $\mathrm{T}_{\mathrm{opt}} \leq \mathrm{T} \leq \mathrm{T}_{\max }$

$\mathrm{TT}=0, \mathrm{~T}>\mathrm{T}_{\max }$,

in which: $\mathrm{T}_{\mathrm{b}}$ is the base temperature; and $\mathrm{T}_{\mathrm{opt}}, \mathrm{T}_{\max }$ and $\mathrm{T}$ were defined in equations (3) to (6). Values of $\mathrm{T}_{\mathrm{b}}, \mathrm{T}_{\mathrm{opt}}$ and $\mathrm{T}_{\max }$ were the same as in the WE model. The schematic representation of the thermal time method is

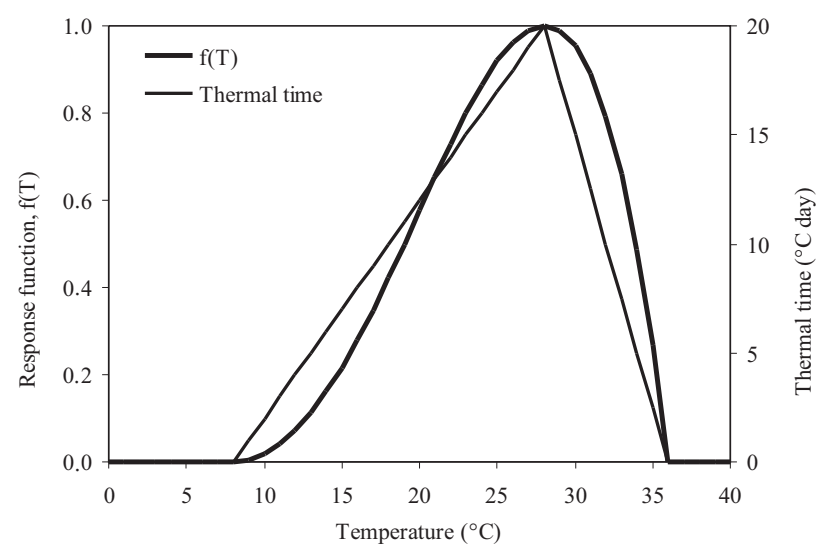

Figure 1. Temperature response function $[f(T)]$ and thermal time model for simulating the phenology of maize, with cardinal temperatures for development $\left(\mathrm{T}_{\min }=8^{\circ} \mathrm{C}, \mathrm{T}_{\mathrm{opt}}=28^{\circ} \mathrm{C}\right.$ and $\left.\mathrm{T}_{\max }=36^{\circ} \mathrm{C}\right)($ Source: Cutforth \& Shaykewich, 1990). in Figure 1. The TT was calculated using daily TN and daily TX and, then, the mean was calculated. The accumulated thermal time (ATT) for each developmental phase (EM-SI and SI-PM) was calculated by accumulating TT.

A two-year field experiment was carried out to evaluate the influence of varying air temperature on the development of the maize variety BRS Missões. This variety was selected instead of a maize hybrid, because it is recommended for small farmers in Southern Brazil (Embrapa, 2006).

The experiment was carried out at the field research area of Universidade Federal de Santa Maria, Santa Maria, RS, Brazil (29 $43^{\circ} \mathrm{S}, 5^{\circ} 3^{\circ} 3^{\prime} \mathrm{W}$; $95 \mathrm{~m}$ ), during two growing seasons, 2005/2006 and 2006/2007, in seven sowing dates each: 21/9/2005, 20/10/2005, 29/11/2005, 4/1/2006, 7/2/2006, 16/3/2006 and 12/4/2006 during the 2005/2006 growing season, and 23/8/2006, 27/9/2006, 30/10/2006, 30/11/2006, 8/1/2007, 13/2/2007 e 15/3/2007 during the 2006/2007 growing season. These sowing dates were selected to have plants developing under contrasting temperatures as they are within and out of the recommended sowing dates for this location (Reunião..., 2005).

The experimental design was a randomized complete block, with six replications. Each plot was $2.4 \times 5.4 \mathrm{~m}$, with three rows in each one in an E-W row direction. Plant spacing was $0.8 \mathrm{~m}$ among rows, and $0.21 \mathrm{~m}$ within rows, with plant density of six plants per square metre. Soil type at experimental site was a Rhodic Paleudalf Argissolo Bruno-Acinzentado alítico típico (Embrapa, 2006). Fertilization rates at sowing in both years were $20 \mathrm{~kg} \mathrm{ha}^{-1} \mathrm{~N}, 75 \mathrm{~kg} \mathrm{ha}^{-1} \mathrm{P}_{2} \mathrm{O}_{5}, 60 \mathrm{~kg} \mathrm{ha}^{-1} \mathrm{~K}_{2} \mathrm{O}$, following soil tests in $0-20 \mathrm{~cm}$ layer. Additional nitrogen was added as side-dress application with urea at $40 \mathrm{~kg} \mathrm{ha}^{-1} \mathrm{~N}$, at V3-V4, V6-V7, V10-V11 and VT developmental stages (Forsthofer et al., 2004). Sprinkler irrigation was used as needed to ensure plants were well watered throughout the growing cycle. Irrigation system was turned on to provide 5 to $10 \mathrm{~mm}$ water, in order to keep crop actual evapotranspiration above $70 \%$ of the maximum one. Insects were controlled by spraying recommended insecticides, and weeds were manually controlled.

Emergence was measured in the three rows of each plot, by counting the number of emerged plants on a daily basis. Emergence date was considered when 50\% of the plants were emerged from the soil surface. When all plants were emerged, plants were thinned to achieve 
the target plant density. One week after emergence, three plants located in the center row, in each replication (plot), were randomly selected and tagged with colored wires. These plants were used to record the SI and the PM dates of the uppermost ear (Ritchie et al., 1997). Dates of SI and PM in each plot were the mean dates of the individual plants (three plants per plot).

Daily minimum (TN) and maximum (TX) air temperature were measured in a standard weather station (8o Distrito de Meteorologia/Instituto Nacional de Meteorologia), about $200 \mathrm{~m}$ from the field site.

Coefficients $r_{\max , v}$ and $r_{\max , r}$, and the ATT for each developmental phase (EM-SI and SI-PM) are genotype-dependent. These coefficients for maize variety BRS Missões were estimated with the SASNLIN (SAS Institute, 2001) procedure, with the Marquardt method using dates of EM, SI and PM, and daily TN and TX data of the seven sowing dates during the 2005/2006 growing season. The ATT for the developmental phases was the mean of the six TT values from each sowing date.

The dates (day of the year, DOY) of SI and PM developmental stages, predicted by the WE and the thermal time models, were compared with the observed values of SI and PM of the seven sowing dates during 2006/2007 growing season, which were independent data sets. The statistics used to evaluate models performance were the root mean square error (RMSE), the index of agreement (d), and the accuracy of model 1 related to model $2\left(\mathrm{E}_{12}\right)$. The RMSE was calculated as (Streck, 2002):

$\left.\operatorname{RMSE}=\left[\Sigma\left(\mathrm{P}_{\mathrm{i}}-\mathrm{O}_{\mathrm{i}}\right)^{2} / \mathrm{N}\right)\right]^{0.5}$

in which: $\mathrm{P}_{\mathrm{i}}$ is predicted DOY; $\mathrm{O}_{\mathrm{i}}$ is observed DOY; and $\mathrm{N}$ is the number of observations. The unit of RMSE is the same as $p$ and o, i.e., days. The smaller the RMSE, the better the model.

The index $d$ measures the degree to which predictions are error-free, and is dimensionless, being calculated as (Streck, 2002):

$\mathrm{d}=1-\left[\Sigma\left(\mathrm{P}_{\mathrm{i}}-\mathrm{O}_{\mathrm{i}}\right)^{2}\right] / \Sigma\left[\left(\left|\mathrm{P}_{\mathrm{i}}-\overline{\mathrm{O}}\right|\right)+\left(\left|\mathrm{O}_{\mathrm{i}}-\overline{\mathrm{O}}\right|\right)\right]^{2}$

in which: $\overline{\mathrm{O}}$ is the mean of the observed values. The values of $\mathrm{d}$ range from 0 , for complete disagreement, to 1 for perfect agreement between observed and predicted DOY.

The statistic $\mathrm{E}_{12}$ was calculated as (Streck, 2002):

$\mathrm{E}_{12}=\mathrm{MSE}_{1} / \mathrm{MSE}_{2}$

in which: $\mathrm{MSE}_{1}$ and $\mathrm{MSE}_{2}$ are the mean square error of the predictions by model 1 and 2, respectively:

$\mathrm{MSE}_{1}=\Sigma\left(\mathrm{P}_{1}-\mathrm{O}\right)$

$\mathrm{MSE}_{2}=\Sigma\left(\mathrm{P}_{2}-\mathrm{O}\right)$
The statistic $\mathrm{E}_{12}$ is dimensionless and varies from 0 to infinity. A value of $E_{12}$, between 0 and 1, implies that model 1 is superior to model 2. If $\mathrm{E}_{12}$ is greater than 1 then model 2 is better. For the purpose of calculating $\mathrm{E}_{12}$, in this study, the WE model was considered model 1 and the thermal time was model 2.

\section{Results and Discussion}

There was a wide variation in environmental conditions, during maize developmental cycles for the different sowing dates, used in the two growing seasons. Minimum air temperature during the EM-SI and SI-PM phases varied from: 6.9 to $25^{\circ} \mathrm{C}$ and from 0.9 to $25^{\circ} \mathrm{C}$, during the 2005/2006 growing season; and from 0.8 to $25.8^{\circ} \mathrm{C}$ and from 1.3 to $25.8^{\circ} \mathrm{C}$, during the $2006 / 2007$ growing season, respectively. Maximum air temperature during the EM-SI and SI-PM phases varied from: 16.6 to $38.6^{\circ} \mathrm{C}$ and from 15 to $38^{\circ} \mathrm{C}$, during the $2005 / 2006$ growing season; and from 12.4 to $38.4^{\circ} \mathrm{C}$ and from 11.8 to $38.4^{\circ} \mathrm{C}$, during the $2006 / 2007$ growing season, respectively. These different temperature conditions, during the two developmental phases, provided a rich data set to estimate model coefficients and to evaluate the two developmental models.

The estimates of $r_{\max , v}$ and $r_{\max , r}$ were 0.0254 and 0.0289 per day, and the estimates of ATT for the developmental phases EM-SI and SI-PM were $734.8^{\circ} \mathrm{C}$ and $655.6^{\circ} \mathrm{C}$ day, respectively. These estimates were obtained from the first five sowing dates of the $2005 / 2006$ growing season, because plants of the two latest sowing dates (16/3/2006 and 12/4/2006) did not flower, due to low temperatures in May and June 2006.

Observed and predicted DOY of SI and PM developmental stages with the thermal time and with the WE models, during the 2006/2007 growing season, are in Figure 2. Plants of 13/2/2007 sowing date did not reach PM, and plants of the 15/3/2007 sowing date did not reach SI and PM, due to low temperatures in April 2007, and died by the end of May 2007 due to frost. By pooling DOY data of all sowing dates, predictions with the thermal time model had a RMSE of 5.6 days and 8.3 days for SI and PM, respectively, and they were greatly improved with the WE model, which had a RMSE of 2.7 days and 4.8 days, for SI and PM, respectively. Other statistics also indicated better performance of the WE model. The index $d$ was 0.9999 and 0.9970 with the thermal time model, and 1.0000 and 0.9989 with the WE model for SI and PM, respectively. The accuracy of the 
WE model in relation to the thermal time model $\left(\mathrm{E}_{12}\right)$ was 0.2356 and 0.3285 for SI and PM, respectively.

The comparison of developmental events predictions using the WE model, with the predictions using the thermal time model, was made for other crops. The WE model was superior to the thermal time one for predicting
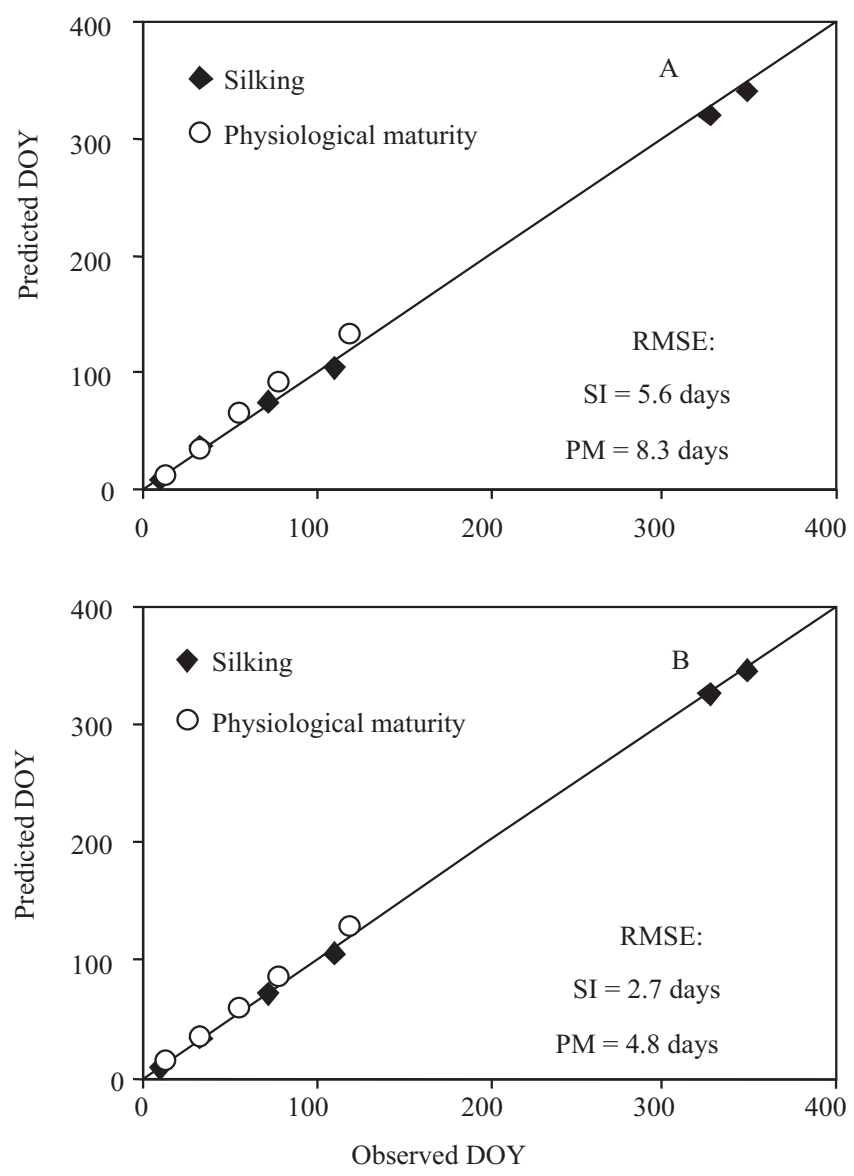

Figure 2. The predicted versus observed day of the year (DOY) of silking (SI) and physiological maturity (PM) of maize variety BRS Missões, by thermal time model (A), and Wang and Engel (WE) model (B). The solid line is the 1:1 line. developmental stages in winter wheat (Xue, 2000) and in potato (Streck et al., 2007); the number of nodes in muskmelon (Streck et al., 2006); and the number of leaves in eucalyptus seedlings (Martins \& Streck, 2007). In these different crops, the WE model had a better performance both in normal sowing dates and out of season sowing dates; and the improvement in the predictions with the WE model was pronounced. For instance, the RMSE for predicting tuber initiation in potato was 4 days with the WE, and 11 days with the thermal time model (Streck et al., 2007); and the RMSE for predicting the number of leaves in eucalyptus seedlings was three and four leaves with the WE model, and seven and ten leaves with the thermal time model, for Eucalyptus grandis and E. saligna, respectively (Martins \& Streck, 2007).

In this study, the WE model gave excellent predictions of silking in all sowing dates, with difference observed minus predicted DOY between 0 and 5 days (Table 1). Differences observed minus predicted DOY were slightly higher for physiological maturity, but predictions were still good with the WE model (from -7 to 0 days). These differences were greater with the thermal time model, which varied from -4 to 10 days for silking, and from -12 to 1 day for physiological maturity (Table 1). Better predictions of early development stages, compared to later ones, with both WE and thermal time models were also reported for potato (Streck et al., 2007).

Errors in the predictions of SI and PM of up to one week in maize are acceptable for many practical purposes. In this study, the thermal time gave an error of 10 days for SI in the 23/8/2006 sowing date, and an error of 9 to 12 days for PM, in three out five sowing dates (Table 1). The WE model performed well in these sowing dates, with errors in the predictions smaller than one week.

Table 1. Difference between observed minus predicted day of the year of silking and physiological maturity of maize variety BRS Missões, with thermal time (TT) model and Wang and Engel (WE) model, in different sowing dates (day/month/year).

\begin{tabular}{|c|c|c|c|c|}
\hline \multirow[t]{2}{*}{ Sowing date } & \multicolumn{2}{|c|}{ Silking } & \multicolumn{2}{|c|}{ Physiological maturity } \\
\hline & TT model & WE model & TT model & WE model \\
\hline $23 / 8 / 2006$ & 10 & 3 & 1 & -2 \\
\hline $27 / 9 / 2006$ & 7 & 3 & 0 & 0 \\
\hline $30 / 10 / 2006$ & 1 & 0 & -9 & -5 \\
\hline $30 / 11 / 2006$ & -4 & 0 & -12 & -6 \\
\hline $8 / 1 / 2007$ & -1 & 1 & -11 & -7 \\
\hline $13 / 2 / 2007$ & 5 & 5 & $-(1)$ & - \\
\hline
\end{tabular}

${ }^{(1)}$ Plants did not reach physiological maturity. 
The WE model should be preferred to thermal time model in maize. There was an overall decrease in the RMSE for SI and PM of 51 and 42\%, respectively, with the WE model (Figure 2). Streck et al. (2007) reported 28 to $45 \%$ of decrease in the RMSE for predicting the date of major developmental stages in potato with the WE model compared with the thermal time approach. Better predictions of developmental stages in maize, with WE compared to thermal time model, are associated to several reasons. First, WE model uses a nonlinear temperature response function, which is more biologically sound to represent plant development response to temperature than a linear response (Bonhomme, 2000). Second, the interaction of nonlinear effects of temperature on plant development is combined in a multiplicative fashion, which is also biologically sound (Streck et al., 2003). Third, the coefficients of WE model $r_{\text {max,v }}, r_{\text {max,r }}$ and cardinal temperatures (minimum, optimum and maximum) have biological meaning and operational definition. These advantages of WE over the thermal time highlight two important features of WE model: robustness while maintaining accurate predictions.

\section{Conclusions}

1. The Wang Engel (WE) model can be used to simulate the phenology of maize, with errors in the predictions of silking and physiological maturity lower than one week.

2. The prediction of developmental stages in maize is superior with the WE model (nonlinear) compared to the thermal time model (linear).

\section{Acknowledgements}

To Conselho Nacional de Desenvolvimento Científico e Tecnológico, Coordenação de Aperfeiçoamento de Pessoal de Nível Superior, and Fundação de Amparo à Pesquisa do Estado do Rio Grande do Sul, for scholarship; to Embrapa Trigo, for providing the seeds; to Alfredo Schons and Ana Paula Schwantes, for technical assistance during the first and second growing seasons, respectively.

\section{References}

BONHOMME, R. Bases and limits to using "degree.day" units. European Journal of Agronomy, v.13, p.1-10, 2000.

COELHO, D.T.; DALE, R.F. An energy-crop growth variable and temperature function for predicting corn growth and development: planting to silking. Agronomy Journal, v.72, p.503-510, 1980.
COSTA, L.C.; BARROS, A.H.C. Desenvolvimento e teste de um modelo de simulação de crescimento, desenvolvimento e rendimento da cultura do milho. Revista Brasileira de Agrometeorologia, v.9, p.75-82, 2001.

CUTFORTH, H.W.; SHAYKEWICH, C.F. A temperature response function for corn development. Agricultural and Forest Meteorology, v.50, p.159-171, 1990.

DAUGHTRY, C.S.T.; COCHRAN, J.C.; HOLLINGER, S.E. Estimating silking and maturity dates of corn for large areas. Agronomy Journal, v.76, p.415-420, 1984.

DAYNARD, T.B. Relationships among black layer formation, grain moisture percentage, and heat unit accumulation in corn. Agronomy Journal, v.64, p.716-719, 1972.

EMBRAPA. Milho BRS Missões. Available at: http:// www.cnpt.embrapa.br/culturas/milho/cultivares/c-missoes.htm. Accessed on: 24 Mar. 2006.

EMBRAPA. Sistema brasileiro de classificação de solos. 2.ed. Rio de Janeiro: Embrapa Solos, 2006. 306p.

FLEISHER, D.H.; SHILLITO, R.M.; TIMLIN, D.J.; KIM, S.H.; REDDY, V.R. Approaches to modeling potato leaf appearance rate. Agronomy Journal, v.98, p.522-528, 2006.

FORSTHOFER, E.L.; SILVA, P.R.F.; ARGENTA, G.; STRIEDER, M.L.; SUHRE, E.; RAMBO, L. Desenvolvimento fenológico e agronômico de três híbridos de milho em três épocas de semeadura. Ciência Rural, v.34, p.1341-1348, 2004.

GILMORE, E.C.; ROGERS JÚNIOR, J.S. Heat units as a method of measuring maturity in corn. Agronomy Journal, v.50, p.611-615, 1958.

GRANIER, C.; TARDIEU, F. Is thermal time adequate for expressing the effects of temperature on sunflower leaf development? Plant Cell and Environment, v.21, p.695-703, 1998.

MAJOR, D.J.; BROWN, D.M.; BOOTSMA, A.; DUPUIS, G.; FAIREY, N.A.; GRANT, E.A.; GREEN, D.G.; HAMILTON, R.I.; LANGILLE, J.; SONMOR, L.G.; SMELTLER, G.C.; WHITE, R.P. An evaluation of the corn heat unit system for the short-season growing regions across Canada. Canadian Journal of Plant Science, v.63, p.121-130, 1983.

MARTINS, F.B.; STRECK, N.A. Aparecimento de folhas em mudas de eucalipto estimado por dois modelos. Pesquisa Agropecuária Brasileira, v.42, p.1091-1100, 2007.

McMASTER, G.S.; SMIKA, D.E. Estimation and evaluation of winter wheat phenology in the Central Great Plains. Agricultural and Forest Meteorology, v.43, p.1-18, 1988.

REUNIÃO TÉCNICA ANUAL DE PESQUISA DE MILHO, 50.; REUNIÃO TÉCNICA ANUAL DE PESQUISA DO SORGO DO RS, 33., 2005: Porto Alegre. Indicações técnicas para o cultivo de milho e sorgo no Rio Grande do Sul 2005/2006. Porto Alegre: Fepagro/Emater-RS/Ascar, 2005. 155p.

RITCHIE, S.W.; HANWAY, J.J.; BENSON, G.O. How a corn plant develops. Ames: Iowa State University of Science and Technology, 1997. 21p. (Special Report, 48).

RUSSELLE, M.P.; WILHELM, W.; OLSON, R.A.; POWER, J.F. Growth analysis based on degree days. Crop Science, v.24, p.28-32, 1984. 
SAS INSTITUTE. SAS-STAT: user's guide. $8^{\text {th }}$ ed. Cary: SAS Institute, 2001.

SCHRODER, U.; SONDGERATH, D. The concept of biological time for computing the switching points of a growth model for winter wheat. Ecological Modelling, v.88, p.1-8, 1996.

SENTELHAS, P.C.; UNGARO, M.R.G. Índices bioclimáticos para a cultura de girassol. Scientia Agricola, v.55, p.1-10, 1998.

STRECK, N.A. A generalized nonlinear air temperature response function for node appearance rate in muskmelon (Cucumis melo L.). Revista Brasileira de Agrometeorologia, v.10, p.105-111, 2002.

STRECK, N.A.; ALBERTO, C.M. Estudo numérico do impacto da mudança climática sobre o rendimento de trigo, soja e milho. Pesquisa Agropecuária Brasileira, v.41, p.1351-1359, 2006.

STRECK, N.A.; LAGO, I.; BURIOL, G.A.; HELDWEIN, A.B.; TIBOLA, T. A non-linear model to simulate node appearance in muskmelon (Cucumis melo L.) grown inside plastic greenhouse as a function of air temperature. Revista Brasileira de Agrometeorologia, v.14, p.210-216, 2006.

STRECK, N.A.; PAULA, F.L.M.; BISOGNIN, D.A.; HELDWEIN, A.B.; DELLAI, J. Simulating the development of field grown potato
(Solanum tuberosum L.). Agricultural and Forest Meteorology, v.142, p.1-11, 2007.

STRECK, N.A.; WEISS, A.; XUE, Q.; BAENZIGER, P.S. Improving predictions of developmental stages in winter wheat: a modified Wang and Engel model. Agricultural and Forest Meteorology, v.115, p.139-150, 2003.

WANG, E.; ENGEL, T. Simulation of phenological development of wheat crops. Agricultural Systems, v.58, p.1-24, 1998.

WARRINGTON, I.J.; KANEMASU, F.T. Corn growth response to temperature and photoperiod. I. Seedling emergence, tassel initation, and anthesis. Agronomy Journal, v.75, p.749-754, 1983.

XUE, Q. Phenology and gas exchange in winter wheat (Triticum aestivum L.). 2000. 123p. Thesis (Ph.D.) - University of Nebraska, Lincoln.

YUAN, F.M.; BLAND, W. Comparison of light- and temperaturebased index models for potato (Solanum tuberosum L.) growth and development. American Journal of Potato Research, v.82, p.345$352,2005$.

Received on September 21, 2007 and accepted on April 2, 2008 